\title{
Demographic Colonialism: EU-African Migration Management and the Legacy of Eurafrica
}

Peo Hansen and Stefan Jonsson

\section{Linköping University Post Print}

N.B.: When citing this work, cite the original article.

This is an electronic version of an article published in:

Peo Hansen and Stefan Jonsson, Demographic Colonialism: EU-African Migration Management and the Legacy of Eurafrica, 2011, Globalizations, (8), 3, 261-276.

Globalizations is available online at informaworld ${ }^{\mathrm{TM}}$ :

http://dx.doi.org/10.1080/14747731.2011.576842

Copyright: Taylor \& Francis (Routledge)

http://www.routledge.com/

Postprint available at: Linköping University Electronic Press

http://urn.kb.se/resolve?urn=urn:nbn:se:liu:diva-59245 


\section{Peo Hansen \& Stefan Jonsson}

\section{Demographic Colonialism: EU-African Migration Management and the Legacy of}

\section{Eurafrica}

\section{Abstract}

In this article we analyse the current trajectory of EU-African migration policy. Unlike many other scholars, we suggest it must be understood in its historical context. Migration between Europe and Africa has been a European concern at least since the 1920s. At that time, issues of migration were seen in the context of a co-European colonial effort in Africa. Today, migration issues are to be resolved in the framework of a EU-African partnership model built on equality, interdependence and mutual 'winwin' dynamics. However, a closer look at the history of EU-African migration reveals striking parallels between past and present. Throughout the period from the 1920 s and onward, the migration policies devised within various frameworks of European integration have been shaped by demographic projections. Presumed demographic 'imbalances' (i.e. population surplus or deficit) have been used to justify vastly different migrant regimes. Each time demography has governed European migration policy vis-àvis Africa, what has first been introduced as a mutual interest has quickly been transformed into a geopolitical relationship, where one partner has channelled migration to its own benefit. We argue that as long as scholars and intellectuals persist in imitating policy-makers' disregard of European integration's colonial history, current structural power asymmetries between the EU and Africa will not only remain obscure; we will 
also fail to recognize the continued, or even increasing, currency of colonial ideology in the EU's African relations. 


\section{Introduction}

The past ten years have seen a rapidly increasing interest in Africa on the part of the European Union. In December 2007 a new 'Strategic Partnership' between the EU and Africa was established. As stated in the Lisbon Declaration: 'We have come together in awareness of the lessons and experiences of the past, but also in the certainty that our common future requires an audacious approach, one that allows us to face with confidence the demands of our globalizing world.' 'On a global scale', the Declaration went on, 'we have today an increased understanding of our vital interdependence and are determined to work together in the global arena on the key political challenges of our time, such as energy and climate change, migration or gender issues.' Furthermore, the Lisbon Summit was hailed as offering 'a unique opportunity jointly to address the common contemporary challenges for our continents, in the year that we celebrate the $50^{\text {th }}$ anniversary of the European integration and the $50^{\text {th }}$ anniversary of the beginning of the independence of Africa'. This provided, the new Africa-EU partnership was presented as a 'partnership of equals', set to eliminate 'the traditional donor-recipient relationship' between the two continents (Lisbon Declaration-EU Africa Summit, 2007).

Speaking at the university in Dakar, Senegal, a few months prior the signing of the Lisbon Declaration, French president Nicholas Sarkozy made an equally bold declaration: 'What France wants with Africa is co-development, shared development ... What France wants with Africa is to prepare the advent of "Eurafrica", a great common destiny which awaits Europe and Africa.' (quoted in Flynn, 2007) 
The new 'partnership' between the EU and Africa goes well beyond the expansion of the long-standing EU-African trade and aid regime, as currently codified in the Cotonou Agreement. Today, Africa is approached as an indispensable 'partner' in the EU's pursuit of a number of key objectives: geopolitical and security concerns (e.g. scarce strategic raw materials, terrorism, 'illegal immigration', trafficking, disease control and food and energy security); economic concerns (e.g. raw materials and expanding outlets for investment in Africa's emerging markets); and demographic and labour market concerns (e.g. labour immigration from Africa).

Considering that it was only ten years ago that The Economist (2000) blazoned abroad 'Hopeless Africa', this is a dramatic reversal of events. Today, hardly a day passes without a report of a major player making a new move in Africa. 'Call us crazy', said the chairman of the Russian investment bank Renaissance Capital, 'but when we look at Africa we believe this will be the fastest growing part of the world ... over the next 20 years' (quoted in Lapper, 2010a). All established and emerging global powers are today involved in an increasingly fierce battle over Africa's riches. Researchers and global media even suggest that we are witnessing a 'new scramble for Africa' (see e.g. Southall and Melber, 2009). To be sure, EU leaders are always fast to deny any such allegation. Distancing themselves from other major stakeholders - foremost China but also the US, India, Russia, Brazil, the Gulf States and Japan — they instead insist that the EU's African engagement is guided by 'interdependence' and committed to a mutually beneficial 'partnership of equals' that will promote development, economic growth, democratic governance, human rights and peace and prosperity on the African continent.

The EU's claim to exceptionalism with regards to democracy, human rights and equality vis-à-vis its competitors is questionable at best. However, as regards migration, 
the EU's relation with Africa must in fact be seen as exceptional. For unlike its competitors, much of the EU's current African venture is bound up with the migration problematic. The stated purpose of the EU is to institute a mutually beneficial 'migration management' between the two continents.

But migration makes the EU's relation to Africa exceptional also in a historical sense. We only need to throw a quick glance at the past to see that migration between Africa and Europe has been a common European concern at least since the 1920s. At that time, issues of migration were seen in the context of a co-European colonial effort in Africa. This historical dimension is precisely what is lacking in existing scholarly analyses of European migration, which are usually governed by a 'presentist' perspective. In previous scholarship there is of course much awareness of colonialism's impact on the current, path dependent migration regimes of individual EU member states, but the equally significant colonial impact of European integration's approach to the nexus of Africa and migration has gone largely unnoticed.

Our aim in this article is to resituate the EU's migration policy toward Africa in the context of European integration's historical relationship with colonial Africa. Only by bringing this by now largely forgotten past into the picture can we begin to understand the motivating forces behind current EU-Africa relations, in general, and the EU's migration policy towards Africa, in particular. In fact, from the interwar period up until the late 1950s nearly all of the visions and institutions working towards European integration placed colonial Africa's incorporation into the European enterprise as a central objective, and linked to this enterprise were plans for managing intercontinental migration. That is, European integration was inextricably bound up with a Eurafrican project (Hansen and Jonsson 2010). For example, in February 1957, as French socialist 
premier Guy Mollet had just concluded the negotiations for the Treaty of Rome, which established the European Economic Community (today's EU), he asserted that a new 'broader unity is being born: EURAFRICA, a close association in which we will work together to promote progress, happiness and democracy in Africa.' (File: EN-2737, Historical Archives of the European Union). For Mollet, the integration of Europe and the constitution of Eurafrica were two sides of the same coin. In current EU studies, however, this goes unmentioned. This may explain why Sarkozy's call for Eurafrica received virtually no commentary as to its historical predecessors. It may also explain why the Lisbon Declaration can convey the impression that the birth of today's EU in 1957 worked to facilitate 'the beginning of the independence of Africa', when, in fact, the institutional arrangements established in the Treaty of Rome were geared in the exact opposite direction (Hansen and Jonson, 2010).

Below, we begin by charting the current trajectory of EU-African migration policy, briefly analyzing its key contents and, in particular, its use of demographic projections. In the second part, we go on to account for the significance assigned to migration between Europe and Africa in the early days of European integration, commencing in the interwar period and culminating in the signing of the Treaty of Rome in 1957. In this way, we seek to relate current migration policies to those that pertained in the early phases of European integration. As we shall see, there is a striking continuity, not so much in regard to the policies per se, but in regard to their source of authorization. This continuity may be theoretically accounted for by what we call a 'demographic logic'. From the 1920s onward, demography has been used to authorize vastly different regimes of migration management, usually with the purpose of evening out perceived 'demographic imbalances' on the two continents. These regimes of migration 
management have always been introduced as being in the best of interest of both continents. However, the shifting and contradictory conclusions that have been drawn from demographic 'evidence' demonstrate how measures first introduced as mutually beneficial have soon been transformed into a geopolitical relationship where the European 'partner' has selected which migrants to invite, and which to repel. In short, by focusing on the colonial motivation of the demographic logic, we disclose the constancy from past to present in the history of EU-African migration.

In doing so, we hope to integrate a historical dimension in the study of current EUAfrican migration policy. In our conclusion we will argue this point in more general terms: as long as scholars and intellectuals persist in imitating policy-makers' disregard of European integration's colonial history, current structural power asymmetries between the EU and Africa will not only remain obscure; we will also fail to recognize the continued, or even increasing, currency of colonial ideology in the EU's African relations.

\section{EU-African Migration Policy Today}

\section{EU Labour Migration in the Post-Zero Immigration Era}

Since 2000, the year that the European Commission officially abrogated its so-called zero labour migration policy towards non-OECD countries, the EU has not missed an opportunity to publicize its dire need to increase the intake of labour migrants from poorer parts of the world. (e.g. CEC, 2005, p. 3-4) This need is often presented as a 
demographic necessity, as in the European Commission's Green Paper on an EU Approach to Managing Economic Migration:

Between 2010 and 2030, at current immigration flows, the decline in the EU-25's working age population will entail a fall in the number of employed people of some 20 million. Such developments will have a huge impact on overall economic growth, the functioning of the internal market and the competitiveness of EU enterprises. In this context ..., more sustained immigration flows could increasingly be required to meet the needs of the EU labour market and ensure Europe's prosperity.

Whether or not the economic crisis and mass unemployment currently afflicting the EU will bring about a revision of the official migration demand remains to be seen. Changes for the short-term have already taken place, but at the time of writing the policy line of significantly increasing labour migration to the EU holds firm.

The EU's abrupt shift from an official policy firmly resolved to uphold 'zero' labour immigration to a policy forecasting the entry of millions of new labour migrants has saddled the Commission and other institutional actors with a tough public relations challenge. Brussels thus appears to be apprehensive that EU citizens will respond negatively to the abrogation of zero immigration, possibly interpreting it as portending less restriction and an uncontrolled inflow of immigrants. In order to obviate a possible public disapproval, the Commission has made sure to promise EU citizens that an increase in labour migration will walk hand in hand with the vigorous implementation of even more forceful measures against 'illegal' migration, so-called bogus asylum seeking 
and international crime and terrorism. As part of this new pledge, the Commission (2002, p. 8) also points to the merits of 'the forced return of illegal residents', arguing that this can help to ensure public acceptance for 'more open admission policies particularly for labour migrants'. Important to mention too is that this has been followed by a pledge to make integration policy more stringent, toughening the stance against the EU's Muslim minority in particular (Hansen and Hager, 2010).

Instead of being a catalyst for a gradual reversal of the EU's securitized migration policy, as many had predicted, the new policy to increase labour migration has thus spawned a development in the exact opposite direction. Between 1993 and 2003, according to the International Centre for Migration Policy Development (2004) in Vienna, more than 10,000 migrants and refugees died in and around the Mediterranean while trying to reach the EU, many of them in search of work. Since then, all estimates point to a steady increase in migrant casualties in the Mediterranean. What we are witnessing, to put it incisively, is a development where the EU's endeavour to increase labour immigration coincides more and more with migrants dying in their endeavour to meet this demand. This has struck many as appallingly irrational, bound to yield to a more expedient regime that would regulate labour migration more in accordance with, for instance, balanced mechanisms of demand and supply. For why roll out more barbwire carpet for those you say you desperately need?

We should add that both Brussels and individual EU governments acknowledge that the reduction of North-South inequalities constitutes the single most important issue to come to terms with so-called forced migration from Africa and elsewhere. As numerous scholars and NGOs have shown, however, the EU lacks both the political will and the viable economic instruments to assume such a far-reaching project, which, needless to 
say, hardly could be initiated short of a sweeping transformation of the current political and economic world order.

\section{EU's African Migration Management}

The EU's current policy approach towards Africa illustrates this condition to the point. On the one hand, the EU needs to control a perceived massive immigration pressure from Africa; or as Nicolas Sarkozy (2007, p. 195-6) has stressed, and again we should note the demographic logic upon which the argument is based:
At our doorstep, 900 million African represent the youth of the world. Four hundred fifty million of them are under seventeen years old. Their poverty and lack of a future are their problem today. Tomorrow these problems will be ours. ... ... No European country will be able to stand up to this challenge if Africans continue to believe that their economic salvation lies in Europe. ... We need to speak frankly with Africans about immigration.

On the other hand, the demographic logic is also used to argue in favour of migration. According to the European Commission (2006, p. 2), the EU needs to 'manage' migration and make sure to admit African migrants:

Migration from Africa has substantially increased in recent months. This development is unlikely to stop in the foreseeable future and migratory pressures may grow. At the same time, the EU will need migrants to ensure the sustainability 
of its labour markets given its demographic development. The EU needs to compete with other world regions and it needs migrants with the appropriate skills to accomplish that.

From 2005 and onwards numerous EU-African declarations, partnerships and other cooperative frameworks (e.g. the European Neighbourhood Policy) have been created in order to establish a mutually beneficial 'management' of African migration. The terms 'migration management' and 'partnership' are key here. They have been adopted for the explicit purpose of clarifying that the EU's intention no longer is focused only on onesided 'control' and 'prevention'. In this equation, the management of migration so as to enhance African development is absolutely central, and is said to be realized through such measures as (non-obligatory) codes of conduct to prevent 'brain drain'; facilitate remittances; assist the return of highly skilled migrants; encourage the role of diasporas and migrant communities in the development of Africa; and to promote democratic governance and human rights (see e.g. The Africa-EU Strategic Partnership, 2007; CEC, 2009, p. 27-8; Joint Africa-EU Task Force, 2010, p. 41-3).

Such and other objectives took shape in the wake of the Ministerial Euro-African Conference on Migration and Development that was held in Rabat in the summer of 2006. The conference was brought about, in part, by the Spanish-Moroccan guard's lethal shooting of more than ten African migrants who, together with several hundred others, were attempting to reach the EU by breaking through the fences surrounding the Spanish colonial enclaves of Ceuta and Melilla, situated on the Moroccan coast. An even greater incentive to the conference consisted of the significantly increased entry of African migrants to the EU in 2005 and 2006. Here both the Spanish government and 
the Commission contended that the long-term solution could not rest with security measures alone, but that it also required measures reducing the disparities between the North and the South (Mead, 2005). In conformity with this, the conference in Rabat adopted both the security and development dimensions of migration on its agenda. But as was indicated above, it was the security approach to migration that got the best of it also in Rabat (Noll, 2006, p. 1). Indeed, the very first concrete measure that came out of the Rabat conference resulted in the setting up of a common EU coast guard that was tasked to patrol the waters between the African mainland and the Canary Islands. As Malta's foreign minister noted with satisfaction, referring to the agreement reached in Rabat: 'Fighting international criminal organisations, repatriation of illegal immigrants and stopping the flow of illegal migration are indeed very important factors in addressing illegal immigration holistically' (quoted in Balzan 2006). As for the development dimension, it certainly was not absent from the conference, but the aid allotted to Africa does not even begin to come near fulfilling its stated purpose, namely to reduce the huge gap in living standards between the EU and Africa.

Notwithstanding the optimism created by the Rabat conference and the swiftly launched measures to stave off the 'illegals', the arrival of African migrants in the Canaries would soon break new records, causing a heated atmosphere within the EU leadership. One point of contention was Spain's decision in 2005 to regularize and thus grant permanent residence to most but not all of its roughly one million undocumented migrants. Many EU governments claimed that this had simply sent the wrong signals. 'It's no solution', the Austrian Home Secretary declared, 'to legalize people, as was done by Spain, because it gives some kind of pull factor to the people in Africa, as we unfortunately saw in the last months.' (quoted in Mahony 2006) The Commission also 
spoke unfavourably about the Spanish regularization; and in the summer of 2008, it went on to announce its formal disapproval of 'mass regularizations' of irregular migrants as such, arguing that it is counterproductive to the 'fight against illegal immigration' (CEC, 2008).

Since the Rabat conference there has been a series of high-level EU-African meetings and agreements focusing on migration. But despite all the rhetoric of "partnership of equals', 'win-win' dynamics and African development, the asymmetric power relations between the EU and Africa shine through with utter clarity when it comes to the more concrete objectives and forms for partnership cooperation (see e.g. Betts, 2008, p. 1314). Going through the scores of policy documents produced by recent EU-African agreements, one is struck by the very weak agency that is assigned to Africa, excluding, that is, its agency as a source of demographic pressure. Similarly, there can be no mistaking which party knows best what is best for Africa.

At the European Commission's meeting with the African Union (AU) in Addis Ababa in October 2006, the Commission presented a package of proposals which may be said to capture the gist of the migration policy that the EU wants to pursue toward Africa in the years to come. The Commission made it plain to its African partner that the EU has a great demand for migrant labour and that it is willing to increase labour migration from unemployment-ridden countries in Africa. But, according to the reports coming out from the meeting, the Commission was equally clear in pointing out that the EU will be the one calling the shots as to who will be admitted and when and where the migrant labour will be needed to fill positions (Brostrand 2006). This was evident from the Commission's concrete proposals and their emphasis on temporary work permits, seasonal labour and 'circular migration', which are in line with the EU's principal 
position on third-country labour migration (Hansen and Hager, 2010). Among other things, Brussels let it be known that an unspecified number of unemployed Africans may, in the near future, be granted temporary work permits in the EU to carry out seasonal work in agriculture, fill positions in the medical service and to work as maids in European households. The Commission also called for a further strengthening of the militarized guarding of the frontier in the Mediterranean and the Atlantic, as well as for closer security cooperation with African countries in order to better combat illegal immigration.

In the subsequent Tripoli Declaration (2006), or the Joint Africa-EU Declaration on Migration and Development, and the EU's Global Approach to Migration (CEC, 2006) this message was repeated. To be sure, both of these policy schemes do include clauses emphasizing all sorts of development benefits to be reaped by African countries from closer cooperation with the EU. Yet, the overarching and most persistent policy prescriptions revolve around the following: that Africa has a 'duty to fully cooperate' with the EU in preventing illegal immigration, developing return instruments and reinforcing border controls; that foreign direct investment in Africa and 'Africa's integration in the global economy' should be promoted; and that circular, temporary and seasonal migration should be facilitated (Tripoli Declaration, 2006; see also CEC 2006). Furthermore, 'policies to increase the economic benefits for the EU from migration' should be enacted to 'facilitate the admission of certain categories of immigrants on a needs-based approach (e.g. highly skilled and seasonal workers)'; and migrants should 'learn the language of their host country' and receive teaching in the 'fundamental European values' (CEC, 2006, p. 7, 8; see also Carrera and Hernández, 2009). 
The EU thus wants to import labour from Africa, but the EU also wants full liberty of choice in deciding who and how many to admit so as to effectively calibrate migration to those sectors presently suffering from labour shortages. In order to assume such control of the migration flows, Brussels considers it an absolute necessity to step up the fight against illegal immigration. Given that labour demand in many sectors may fluctuate quite rapidly the EU also wants to guard itself against a situation where newly arrived labour migrants all of a sudden are out of work, with all that this involves in terms of social and economic costs. It is by recommending temporary and circular migration, as well as preparing for an active return policy if jobs should dry up, that Brussels wants to obtain instruments to avert such a situation.

Taken together, the EU's migration policy towards Africa is emblematic not of EUAfrican win-win dynamics and African development gains, but rather of how Brussels, in a practical sense, believes itself capable of generating a win-win dynamic between its own security-oriented fight against illegal migration, on the one side, and its neoliberal fight for growth and competitiveness, on the other.

In their thorough assessment and analysis of the EU's African partnership policy on labour migration, Carrera and Hernández (2009, p. 36) demonstrate that the type of labour migration 'envisaged by the partnerships is guided by a logic that views mobility as circular, temporary and subject to selection'; it is thus a logic that 'mainly serves the national interests and political agendas of the participating EU member states while increasing the vulnerability of third-country workers'. As the Commission (2007, p. 8) explains, 
Circular migration is increasingly being recognized as a key form of migration that, if well managed, can help match the international supply of and demand for labour, thereby contributing to a more efficient allocation of available resources and to economic growth. However, circular migration also poses certain challenges: if not properly designed and managed, migration intended to be circular can easily become permanent and, thus, defeat its objective.

To migrate to the EU with one's much sought-after labour has ceased to be synonymous with the simultaneous option to also migrate into a regime of social rights of citizenship. This also means that the precarious and rightless position that has made 'illegal' labour migrants so popular on the EU labour market in some important respects now forms the model for how the EU is to go about managing its great demand for new 'legal' labour migrants. As a consequence, the very same people on whom the EU's future economic growth, global competitiveness and demographic health are said to depend are offered nothing in return. This points to an attempt to further disembed migration policy from policies of social incorporation, an attempt which is structurally interlinked with a simultaneous effort to capitalize even further on the international division of labour by way of establishing this division more firmly and tangibly in the heart of Europe itself. This course of action will not only risk exacerbating ethno-racial exclusion and adding further tiers to the EU's already multi-tiered labour market; with a militarized migration control serving as its ultimate regulator it will also risk worsening the migration crisis at the EU's external borders.

In sum, it seems as if the EU wants Africa's labour, but not the Africans, at least not in the form of prospective rights-bearing citizens. Despite the panic over the EU's 
allegedly tremendous and ominous demographic deficit, there is thus no mention of population replacement in EU policy discourse. As we shall see below, European integration's historical relationship with Africa offers yet another lesson on these matters.

\section{The Eurafrican Legacy}

\section{Interwar Debates on European Emigration to Africa}

Ours is not the first time that exposure of Africans on European territory causes concern among European policy makers. Arguably, the first major inter-European debate on importation of African labour and service personnel erupted during and after World War One. Camped in Europe were at that time hundreds of thousands soldiers born in the colonies of the European states, many of them Africans fighting on the French and the British sides. Immediately after the war, troops from Madagascar, French Equatorial and West Africa, Morocco and Algeria patrolled the streets of the occupied territories of Germany’s Rhineland (Koller, 2001, 87-102).

German newspapers were soon flooded with articles disseminating rumors of atrocities committed by these black and Arab troops. African soldiers were generally described as savages who posed great danger especially for the German female and juvenile population. In 1923, as French troops including a fraction of African units occupied the strategically important Ruhr area, the outcry was amplified. Germans of course protested against France's infringement on their economic autonomy. But they also condemned France's violation of an even more fundamental law, which president 
Friedrich Ebert defined: 'the deployment of coloured troops of the most inferior culture as overseers of a population of such high spiritual and economic importance as the Rhinelanders is an intolerable violation of the law of European civilization' (quoted in Koller, 2001, p. 324, emphasis added). Hitler, for his part, spoke of the colonial troops in terms of "the contamination by Negro blood on the Rhine in the heart of Europe ... bastardizing the European continent at its core' (quoted in Lusane, 2003, p. 80). He was certainly in good company, similar opinions reaching well into Western Europe's liberal and social democratic establishments, as well as into prominent women's organizations (Nelson, 1970; Lusane, 2003).

The deployment of 'blacks' on 'white' soil had already during the war become a subject of diplomatic contention, as Germany demanded that France restrict the visibility of Africans in occupied territories (Nelson, 1970, pp. 609-612). This is why World War One and its aftermath merit attention. It is the first time that European politicians and diplomats negotiate on how to limit the number of Africans in Europe, while at the same time recognizing that Africans were needed, as soldiers, in Europe. Even if no formal agreement was signed, a gentlemen's agreement prevailed to the effect that all involved found the idea of African migration and settlement in Europe deeply repulsive.

'The Black Horror' thus encouraged interstate collaboration and mutual understanding within Europe. Soon, a spirit of rapprochement would also emerge regarding other aspects of the Franco-German conflict. For it is of course in the geographic area at the crux of this conflict that we locate the origins of the history of the EU, which usually claims as its precursor the so-called Schuman declaration of 1950 and the establishment of the European Coal and Steel Community a year later. Schuman's project, in turn, originated in similar plans, circulating from the early 1920s and onward, on how to 
resolve the centuries-long strife over the border region and its rich resources in coal and iron.

According to many intellectuals and politicians of the period, the occupation of the Rhineland and the Ruhr region demonstrated that the age-old animosity between France and Germany had led both states into a dead end. Henceforth, the survival of each state depended on the ability of both to collaborate with one another. This argument was expressed by Richard Coudenhove-Kalergi, founder of the Pan-European movement. In his program pamphlet Paneuropa, he promoted the Rhur and Rhineland crises as the first key incitement — of two-leading to European integration: 'Out of the terrifying crisis in which Germany and France are locked today, they will either emerge as united Europeans - or they will, biting at each others' throats, bleed to death from their mutually inflicted wounds.' Europe must unite in a Pan-European union, and the first step in this process must be taken by France and Germany, Coudenhove-Kalergi argued (Coudenhove-Kalergi, 1926, pp. 107-122).

Coudenhove-Kalergi's argument for a European union mirrors the world view of internationalists and liberal progessives of his era. A united Europe was paramount for political reasons, or simply to prevent a repetition of World War One. A united Europe was desirable also for cultural reasons, as history seemed to indicate that Europe made up some sort of civilizational unit. In addition, the 1920s added a third, economic argument, for as Europeans compared their own states to the rapidly growing economies of the United States and the Soviet Union, they concluded that both enjoyed the advantage of operating on a continental scale, whereas Europe was torn apart and its economic size and dynamism suffering because of trade and customs barriers. 
This economic perspective then gradually turned into a geopolitical and demographic one, which touched the sensitive issue as to whether Europe would ever be able to regain its place as a world power on a par with the other ones. In this context we discover Coudenhove-Kalergi's second key incitement for a European unification. Sursprisingly—or should we say predictably? -Africa here again turned up on the agenda. For in the same way as Africa, intruding into the heart of Europe, previously had been seen as a problem that made Europeans close ranks, it now returned as a common concern, but this time as a promise and possibility.

Africa was here looked at as a provider of natural resources and energy. But Africa was also seen as a solution of Europe's demographic problems, as it was widely agreed that Europe was overpopulated. As Coudenhove-Kalergi stated in his essay 'Afrika': 'Africa could provide Europe with raw materials for its industry, nutrition for its population, land for its overpopulation, labour for its unemployed, and markets for its products'. (Coudenhove-Kalergi, 1929, p. 3) The joint development of Africa appeared as an aim so unquestionably good, that it in itself would be a reason for the European states to make common cause. A geopolitical calculation emerged in which two good things reinforced one other: by uniting Europe a new geopolitical sphere would emerge that thanks to its inclusion of Africa would be sustainable and prosperous; and by developing Africa together the bonds of peace and collaboration would grow stronger between once antagonistic European states.

Contrary to the standard understanding of EU historiography, in which CoudenhoveKalergi is hailed as the father figure of the founding fathers, his idea of Pan-Europa was not limited to Europe alone but also included Africa. These 'Eurafrican' blueprints of the interwar period were experimental drafts, which after World War Two served as 
frames of reference for various institutions promoting European integration, which culminated in the founding of today's EU in 1957-a process of historical genesis by now largely forgotten by everyone except a handful of specialists.

However, in today's proposals for a 'new' EU-Africa partnership certain aspects of this repressed history return, not only in the sense that many of Europe's aims and stakes in Africa seem to have remained constant since the congresses of the Pan-European Union, but also in the sense that 'the migration problem' and the demographic logic associated with it have yet again reached the top of the agenda.

At the fourth congress of the Pan-European Union in 1935, Africa was discussed as a solution for Europe's problem of overpopulation. Philosopher Max Grünewald (1935) presented a report, 'Africa and the Problem of Emigration', that suggested that twelve million unemployed Europeans should be moved to Africa. Engineer Artur Biber showed statistics in favour of the establishment of a 'New Europe' in Africa, to be placed under the authority of the League of Nations, populated by three million Europeans and furnished by a sizeable investment fund (Fleury, 2005, p. 51). Grünewald ended his report by quoting Coudenhove-Kalergi: 'To save Africa for Europe, is to save Europe by way of Africa.'

In the interwar period, and especially during the 1930's economic depression, both these objectives—saving Europe and controlling Africa—hinged on the question of large-scale European emigration to Africa. Another important supporter of European integration, French geographer Eugène Guernier, opened his 1933 book Afrique: Champ d'expansion de l'Europe (Africa: Field of European Expansion), with a fifty-page survey of world migration over the past century. For each European country, Guernier introduced an abundance of demographic data; and for each country he reached the same 
apparently irrefutable conclusion. Italy, for example, 'will again find itself before the necessity to imagine a way of securing the livelihood of its annual nativity surplus amounting to 455000 people, a great part whom, unable any no longer to cross the Atlantic, or the Alps, ... should start looking toward Africa.' (Guernier, 1933, p. 27) $\underline{\text { Orsinini IN }}$

According to Guernier, no single European state owned the resources to organize and finance the required settlements. Therefore, European cooperation was necessary. Guernier suggested a three-step strategy. First, the European states should select the best and brightest of its elite, and send them to Africa to draw up concrete plans and projects of development. These elites would then prepare the way for the 'troupes de choc: engineers, constructors, entrepreneurs, and builders, who, in providing Africa with its material necessities, will allow the already evolved parts of the indigenous races to improve their standard of life' (p. 266). Once this new Eurafrican order was set in place, mass-migration of Europeans at an annual rate of 500000 would follow, totalling, in thirty to fifty years, twenty million individuals (p. 270-1).

Guernier's plan was but one of the more elaborate among similar ones that circulated in France of the 1930s. Support for a common European development of Africa was found at the top political level. Albert Sarraut, prime minister and major radical politician of the third republic, made plans similar to those of Coudenhove-Kalergi, including the idea of using Africa as an outlet for the superfluous part of the European labour force, for whom Africa could become 'a new workshop' (Montarsolo, 2005, p. 80-2). REYNAUD!!! Other French politicians on the left endorsed similar ideas (Ageron, 1975), which were propagated in many other European countries as well. In its typical form, the demographic argument for the creation of Eurafrica drew support from 
Friedrich Ratzel's theory of 'Lebensraum'. World War One, the German inflation of 1923, the great crash of 1929 and the ensuing depression were all taken as symptoms of Europe's lack of 'vital space'.

\section{The Demographic Argument in the Postwar Period}

Interestingly, this view prevailed after World War Two, a catastrophe that demographers now added to the list of proofs of their theory of overpopulation. While it is well known that, beginning in 1945, plans were developed and institutions established to care for the millions of refugees made stateless by the war, it is rarely remembered that corresponding plans and institutions were set in place to encourage overseas emigration of the three-to-five million inhabitants, who were 'excessive', according to demographic analyses. In 1951 was created in Brussels the Provisional Intergovernmental Committee for the Movement of Migrants from Europe (today the International Organization for Migration). The institutional framework for handling refugees was thereby separated from that which dealt with the 'migrant' population (Karatani, 2005). As the name of the new organization spelled out, this population should be 'moved from Europe'.

That Europe was overpopulated, and immigration to Africa was a solution, was dogma in European social sciences of the early 1950s, as may be witnessed, for instance in the works of influential demographer Albert Sauvy (1953), head of Institut national d'études démographiques. According to Robert Rochefort, Robert Schuman's former chief of cabinet and diplomatic counsellor to the Intergovernmental committee for the Movement of Migrants, a coordinated effort was needed to help over-crowded Austria, West-

Germany, Italy, Greece and Netherlands, and encourage its populations to settle 
elsewhere. Rochefort produced a demographic argument for an accelerated European integration that resonated well with the Europeanist politics of his peer Robert Schuman (Rochefort, 1954, pp. 148, 152-3). Unless the west European states found a common solution to the endemic problem of overpopulation, Europe would be exposed to all kinds of dangers ranging from famine to communism.

Rochefort mentioned Canada, Brazil and Australia as possible destinations for European migrants, but he was more attracted to 'the Eurafrican framework' - 'where immense territories are waiting to rise from their secular slumber and abandonment' (Rochefort, 1954, 154f.). A plausible reason for this preference may have been that by this time Eurafrica was well defined as a political project, partly thanks to the initiative of Robert Schuman himself, who in the Schuman Declaration, which gave birth to the European Coal and Steel Community, had stated: 'With increased resources Europe will be able to pursue the achievement of one of its essential tasks, namely, the development of the African continent.' (Declaration of 9 May 1950).

Even more important in this context was the work conducted by the Council of Europe (CE), which immediately after its founding in 1949 succeeded in turning Eurafrica into one of the organization's defining priorities (see Palayret, 2005, pp. 200-213; Heywood, 1981), a fact almost forgotten today.The unanimous adoption of the 'Strasbourg Plan' by the CE's Consultative Assembly in 1952 provides ample testimony to the Eurafrican momentum during the 1950s. Built on an extensive expert report by the Consultative Assembly's Secretariat-General as well as the work within the OEEC, the Plan set out to resolve one of Western Europe's most pressing problems at the time, namely its chronic and paralyzing dollar deficit. The answer? Africa! As German representative Johannes Semler, heading the CE's Committee on Economic Relations with Overseas Territories, 
pleaded for the Plan before the Assembly, he quoted from a speech made a week earlier by Paul Reynaud, former prime minister and colonial minister of France, and now chairman of the CE's Committee on Economic Questions: 'We must also, if free Europe is to be made viable, jointly exploit the riches of the African continent, and try to find there those raw materials which we are getting from the dollar area, and for which we are unable to pay.' (CE, 1952, p. 135) In so doing, this would facilitate Western Europe's transition into 'a third economic group standing mid-way between the Communist and the dollar areas' (CE, 1952, p. 15). However, since the large-scale investments required could not be shouldered by the colonial powers alone, the Plan was adamant in stressing the indispensability of all Council members (by now 14 countries) contributing.

The topic of European emigration to Africa also figured prominently in the Strasbourg Plan, since Western Europe's 'over-population' of some five million people was seen as 'one of Europe's most critical human and social problems' (CE, 1952, p. 58). 'What must be determined', the Plan stated, 'is the extent to which a co-ordinated policy is likely to encourage emigration, particularly from Western Europe to overseas countries, to the benefit of all concerned.' 'It is encouraging', the Plan went on to note, 'that a number of European countries are prepared and indeed eager to foster overseas emigration of their nationals' (CE, 1952, p. 58). Save for Italy's demand to provide for mass emigration to African colonies, however, the majority opinion within the Council of Europe opted for a more moderate approach, mostly advocating emigration of skilled Europeans. As the Strasbourg plan argued, 'it would be to the advantage of all concerned if African demands for skilled labour could, so far as possible, be met'. Yet again, though, this presupposed a concerted European effort that facilitated not only the 
emigration from the colonial, metropolitan countries, but also from Western Europe as a whole (CE, 1952, p. 59).

With the presumed availability of five million potential colonizers, all these initiatives appeared both rational and convincing. Large parts of the European political leadership described Eurafrica as a project able to convert demographic problems into possibilities, economic disadvantages into advantages, multi-state fragmentation into supra-state integration, and all this through a magic formula in which Eurafrica functioned both as a raison d'être of a unified Europe, and as the most glorious achievement of such a union.

What did the African 'partner' think of such plans? According to Jean Fremigacci (2005), who has studied the positions of the African delegates to the French National Assembly, they in fact agreed as to the dogma that Europe was overpopulated. However, African leaders were fiercely opposed to the prospect that the European community would allow citizens of European member states to settle in Africa. Influx of workers from Germany and Italy would deprive the native working class of work, they argued. They also resented a foreseen invasion of 'petits blancs' (a white underclass): it is in the nature of 'les petits blancs' to 'exude racism as naturally as the human skin perspirates', wrote Léopold Sedar Senghor. Sourou Migan Apithy of Dahomey (Benin) struck at the heart of the matter as he dared to reverse the question, thus disclosing the reality of the Eurafrican project. 'And what about us, we Africans?', Apithy asked calmly. 'Will we enjoy the same right of free movement in Europe?' (Fremigacci, 2005, p. 5-7).

On this aspect of the Eurafrican collaboration, Coudenhove-Kalergi had set the tone from the outset. In his 1929 article on Africa, in which he asserted the need for a coEuropean colonization, he also stated that 'we must at all costs' prevent 'that great numbers of black workers and soldiers immigrate to Europe' ('soldiers' of course being 
an allusion to France's disputed use of black troops in its occupations of Germany; Coudenhove-Kalergi, 1929, p. 5). Influential French demographer Xavier Lannes, writing in 1953, made the same point explicit: immigration of 'natives' to metropolitan centres had to be forcefully restricted (Lannes, 1953, p. 17).

Most often, however, that point went without saying. That it did not need to be expressed reveals some of the hidden armature of the Eurafrican project: an ingrained belief that the presence of Africans in Europe was an absurdity, an offense, whereas the presence of Europeans in Africa was a necessity. It is on this level that we discover the remarkable constancy of the Eurafrican project from its inception until present: there is always free movement, agency and driving force, but only from one direction. In the 1950s, the European proposals for an integrated Europe along with its African possessions at least found support in demographic logic. After all, if it was true that Europe had an excess of millions of people, it was easy to make rational arguments in favour of emigration to Africa and against immigration into Europe. Today, it is not so easy, as demographic figures have shifted in the opposite direction. Which is why today's EU policies, as we have seen, are bound to appear contradictory.

In the 1950s, Alfred Sauvy was almost alone in being able to envision such a scenario. There are today one million French-born in Algeria, but only 300,000 Algerian-born in metropolitan France, he stated in 1953. But what if the tide turns? 'A liberation of the movement of people between European states will entail an identical liberation of movement for Algerians.' If tomorrow a man from Naples or Brabant can settle in Paris, then, too, a man from Kabylia can settle in Naples or Limburg. 'Even if this scenario is premature', Sauvy wrote, 'it, too, may be a cause of conflict that merits careful investigation' (Sauvy, 1953, p. 16). In the Treaty of Rome, which stipulated the 
incorporation into the EEC not only of France's departments in Algeria and its other overseas departments, but also the economic association with the Community of all the member states' colonial possessions (Hansen and Jonsson, 2010), such apprehensions were resolved. Thus, while Algeria was incorporated into the EEC and, inter alia, its regime of free movement of goods, the Algerians were not covered by the provisions allowing for the 'freedom of movement for workers' within the Community (see Treaty establishing the European Economic Community, 1957, art. 227).

\section{Conclusion}

Fifty years later, we have arrived: Europe's population appears to be shrinking; Algerians and other Africans inhabit Naples and Limburg. Today, as fifty years ago, demographic projections rule supreme when it comes to inventing and supporting arguments in favour of this or that policy of migration. Unchanged as well is the idea that Europe's future rests in Africa. And most permanent of all is the aversion to the prospect of having Africans permanently settle on EU territory. It is true that none of these conclusions is surprising, much less unexpected. Still, they indicate the long-term historical perspective in light of which today's EU policies of migration and security should be evaluated, as well as the undesirable aspects of the legacy that these policies seem unable to redress, for the simple reason that that legacy remains unacknowledged.

Today, as we noted at the outset, the EU proclaims that it nurtures an 'awareness of the lessons and experiences of the past' and that it is intent to abolish 'the traditional donor-recipient relationship' between Europe and Africa. Yet, when scrutinizing the actual policy developments, the state of affairs may be more appropriately described as 
one where EU-African relations are moving forward to the past. Or as Gordon Brown announced in 2005: 'I've talked to many people on my visit to Africa and the days of Britain having to apologise for its colonial history are over. We should move forward. We should celebrate much of our past rather than apologising for it.' (quoted in Brogan, 2005) 'We've especially got to stop excusing them from all responsibility for the underdevelopment of their continent', says Nicolas Sarkozy (2007, p. 196); 'Blaming Africa's failure only on the consequences of colonialism is contrary to reality.' Such statements, which have become more and more frequent in recent years, have to be made in order to make the EU's new scramble for Africa seem legitimate and, above all, 'new', built, as it is, around euphemisms of partnership of equals, interdependence, mutual benefits and the like.

As we have argued, the recent EU-Africa strategic partnership is not as new as it may seem, and this is most clearly seen in the area of migration. In the period from the $1920 \mathrm{~s}$ and onward, the migration policies of the EU and its predecessors have been largely shaped by demographic projections, and this regardless of whether these actors have promoted emigration from Europe, immigration into Europe, or so-called circular migration. Presumed demographic 'imbalances' (i.e. population surplus or deficit) have been used to justify a range of different migrant regimes. And depending on whether the surplus has been found in Europe or in Africa, a corresponding regime of migration has been set in place that has either promoted migration, or restricted migration, or sought to do both at the same time. If the changeability seems to prove the adaptable, flexible, or even self-contradictory nature of European migration policies, at a deeper level it also indicates a striking constancy. In the various Eurafrican partnerships that have been promoted since the 1920s, power and agency have always been on the European side, 
while Africa has figured as a safety valve ensuring Europe's biopolitical stability. Each time demography has governed European migration policy vis-à-vis Africa, what has first been introduced as a mutual interest, or a 'partnership of equals', has quickly been transformed into a geopolitical relationship, where one partner has channelled migration to its own benefit.

Indeed, in the current debate on the global economic downturn it is possible to discern yet another take, in which the same demographic projections that until recently envisioned large circular flows of migrants coming into Europe are now used to promote, as in the 1920s, a new wave of emigration from Europe to Africa. Says Martin Wolf (2010) of the Financial Times: 'this leaves peripheral [EU] countries in a trap: they cannot readily generate an external surplus; they cannot easily restart private sector borrowing; and they cannot easily sustain present fiscal deficits. Mass emigration would be a possibility, but surely not a recommendation.' Or in more assertive terms argues Jack Goldstone (2010, p. 43) in Foreign Affairs:

One somewhat daring approach to immigration would be to encourage a reverse flow of older immigrants from developed to developing countries. If older residents of developed countries took their retirements along the southern coast of the Mediterranean or in Latin America or Africa, it would greatly reduce the strain on their home countries' public entitlements systems. The developing countries involved, meanwhile, would benefit because caring for the elderly and providing retirement and leisure services is highly labor intensive. Relocating a portion of these activities to developing countries would provide employment and valuable training to the young, growing populations of the Second and Third Worlds. 
Goldstone's daring suggestion may already be partly realized in Angola, where at least 100,000 Portuguese have settled over the past three years, according to the Financial Times: 'With Portugal's economy hard hit by the international finance crisis recession and unemployment rising, thousands of Portuguese have flocked to the oil- and diamond-rich country.' (Lapper, 2010b)

Thus, we should guard against hasty conclusions as to the dead certainty about the current long-term demographic projections, all predicting a circular migration traffic of African labour to-and-fro the EU.

A closer historical analysis of the policies of migration involving Africa and Europe would certainly be able to prove demography's role as a servant of a colonial or neocolonial system of unequal exchange. Although the modes of implementing this regime have changed during the decades surveyed in this article, the regime itself remains remarkably intact. From its inception, this regime designated itself as Eurafrica. And Eurafrica has typically expressed itself as a demographic necessity, that is, a geopolitical entity justifying itself simply as the most rational way of reaching demographic equilibrium. That Europe and Africa are bound to a common Eurafrican destiny, and that migration between them should be regulated accordingly, constitute a basic presumption of demographic science as developed within the European or geopolitical frame ever since the 1920s. What we have explored here is therefore not merely how demography has served Europe's dominance over Africa, but demography as colonialism, or, in a word, demographic colonialism. 


\section{References}

Balzan, A. (2006) Europe and Africa agree on common plan to tackle migration, EUobserver, euobserver.com, 12 July.

Brogan, B. (2005) It's time to celebrate the Empire, says Brown, Daily Mail, 15 January.

Brostrand, K. (2006) Afrikanska unionen överväger EU-förslag, Ekot (Swedish Radio), 2 October, http://www.sr.se/cgi-bin/ekot/artikel.asp?artikel=957597.

Carrera, S. and Hernández, R. (2009) The Externalization of the EU's Labour Immigration Policy, CEPS Working Document No. 321, October (Centre for European Policy Studies).

CEC (2002) Green Paper on a Community Return Policy on Illegal Residents, COM(2002) 175 final, Brussels, 10 April.

CEC (2005) Green Paper on an EU Approach to Managing Economic Migration, $\operatorname{COM}(2004) 811$ final, Brussels, 11 January.

CEC (2006) The Global Approach to Migration one year on, COM(2006) 735 final, Brussels, 30. 11. 
CEC (2007) On circular migration and mobility partnerships between the European Union and third countries, $\mathrm{COM(2007)} 248$ final, Brussels, 16. 5.

CEC (2008) A Common Immigration Policy for Europe: Principles, actions and tools. $\operatorname{COM}(2008) 359$ final, Brussels, 17. 6.

CEC (2009) Implementation of the Joint Africa-EU Strategy and its Fist Action Plan (2008-2010), SEC(2009) 1064 final, Brussels, 20. 7.

Coudenhove-Kalergi, R. N. (1926 [1923)] Paneuropa, 2nd ed. (Wien \& Leipzig: Paneuropa-Verlag).

Coudenhove-Kalergi, R. N. (1929) Afrika, Paneuropa 5(2).

CE (Council of Europe) (1952) The Strasbourg Plan, Strasbourg: Secretariat-General Council of Europe.

Declaration of 9 May 1950, http://europa.eu/abc/symbols/9-may/decl_en.htm.

Fleury, A. (2005) Paneurope et l'Afrique, in M-T. Bitsch and G. Bossuat (eds.) L'Europe unie et l'Afrique: De l'idée d'Eurafrique à la convtion de Lomé I (Brussels: Bruylant). 
Flynn, D. (2007) Sarkozy proposes 'Eurafrica' partnership on tour, Reuters, 26 July, http://www.reuters.com/article/idUSL26102356?sp=true\&view=sphere.

Fremigacci, J. (2005) Les parlementaires africains face à la construction européenne, 1953-1957, Matériaux pour l'histoire de notre temps, 77, pp. 5-16.

Goldstone, J.A. (2010) The New Population Bomb, Foreign Affairs, 89(1), pp. 31-43.

Guernier, E-L. (1933) L'Afrique. Champ d'expansion de l'Europe (Paris: Armand Colin).

Hansen, P. and Hager, S.B. (2010) The Politics of European Citizenship: Deepening Contradictions in Social Rights and Migration Policy (New York: Berghahn Books, forthcoming).

Hansen, P. and Jonsson, S. (2010) Bringing Africa as a 'Dowry To Europe': European Integration and the Eurafrican Project, 1920-1960 (forthcoming).

Heywood, R.W. (1981) West European Community and the Eurafrica Concept in the 1950s, Journal of European Integration 4(2): 199-210.

International Centre for Migration Policy Development (2004) Irregular transit migration in the Mediterranean, Vienna. 
Joint Africa-EU Task Force (2010) Report of the $10^{\text {th }}$ Meeting of the Joint AUC-EC Task Force, Brussels, 18-19 March.

Karatani, R. (2005) How History Separated Refugee and Migrant Regimes: In Search of Their Institutional Origins, International Journal of Refugee Law, 17(3), pp. 517-41.

Koller, C. (2001) 'Von Wilden aller Rassen niedergemetzelt': Die Diskussion um die Verwendung von Kolonialtruppen in Europa zwischen Rassismus, Kolonial- und Militärpolitik (1914-1930) (Stuttgart: Franz Steiner Verlag).

Lannes, X. (1953) Les problèmes de main d'oeuvre dans l'Eurafrique, La nouvelle revue française d'outre-mer 3, Suppl. 17.

Lapper, R. (2010a) Russian bank nears brokerages deals in push to dominate Africa, Financial Times, 30 March.

Lapper, R. (2010b) Angola welcomes return of former colonial power, Financial Times, 7 January.

Lisbon Declaration—EU Africa Summit (2007), Lisbon, 8-9 December, http://www.africa-eu-partnership.org/documents/documents_en.htm.

Lusane, C. (2003) Hitler's Black Victims (New York: Routledge). 
Mahony, H. (2006) EU states bicker over immigration issues, EUobserver, euobserver.com, 22 September.

Mead, N (2005) Melilla: bloodbath on the African-Europe frontier, openDemocracy, 10 October, http://www.opendemocracy.net/people-migrationeurope/melilla_2905.jsp,.

Montarsolo, Y (2005) Albert Sarraut et l'idée d'Eurafrique, in M-T. Bitsch and G. Bossuat (eds.) L'Europe unie et l'Afrique: De l'idée d'Eurafrique à la convention de Lomé I (Brusells: Brulyant).

Nelson, K. L. (1970) The 'Black Horror on the Rhine': Race as Factor in Post-world War I Diplomacy, The Journal of Modern History, 42(4), pp. 606-27.

Noll, G. (2006) The Euro-African migration conference: Africa sells out to Europe, openDemocracy, 14 July.

Palayret, J-M. (2005) Les mouvements proeuropéens et la question de l'Eurafrique, du Congrès de La Haye à la Convention de Yaoundé (1948-1963), in M-T. Bitsch and G. Bossuat (eds.) L'Europe unie et l'Afrique: de l'idée d'eurafrique à la convention de Lomé I (Brussels: Bruylant).

Rochefort, R. (1954) L'Europe et ses populations excédentaires, Politique étrangère 19(2), pp. 143-56. 
Sarkozy, N. (2007) Testimony: France, Europe, and the World in the Twenty-first Century (New York: Harper Perennial).

Sauvy, A. (1953) Un plan d'études, Population, 8(1), pp. 4-20.

Southall, R. \& Melber, H. (eds.) (2009) A New Scramble for Africa? Imperialism, Investment and Development (Scottsville: University of KwaZulu-Natal Press).

The Africa-EU Strategic Partnership (2007), Lisbon, 8 December, 2007, http://www.africa-eu-partnership.org/documents/documents_en.htm.

The Economist (2000) Hopeless Africa, Leaders, 11 May.

Treaty establishing the European Economic Community (1957) Rome, 25 March.

Tripoli Declaration (2006) Joint Africa-EU Declaration on Migration and Development, Tripoli, 22-23 November, http://www.unhcr.org/refworld/docid/47fdfb010.html.

Wolf, M. (2010) The eurozone's next decade will be tough, Financial Times, 5 January. 